\title{
Characterization of a Novel Cell Line (HCH-3) Derived from a Human Ovarian Clear Cell Carcinoma
}

Takashi Yamada ${ }^{1 *}$, Kimiaki Hattori' ${ }^{1}$, Hidetoshi Satomi ${ }^{1}$, Tadashi Okazaki ${ }^{2}$, Hiroshi Mori ${ }^{3}$ and Yoshinobu Hirose ${ }^{1}$

${ }^{1}$ Department of Pathology, Osaka Medical College, 2-7 Daigaku-machi, Takatsuki, Osaka 569-8686, Japan

${ }^{2}$ Department of Obstetrics and Gynecology, Hirakata City Hospital, 2-14-1 Kin-yahommachi, Hirakata, Osaka 573-1013, Japan

${ }^{3}$ Department of Clinical Pathology, Minoh City Hospital, 5-7-1 Kayano, Minoh, Osaka 562-8562, Japan

\begin{abstract}
Objective: Established cell lines are important materials helping a medical basic research. The reports listed in detail of the cell line derived from an ovarian clear cell carcinoma were only 14 , so far. Owing to little information, the establishment of malignant tumor cell line with individual characteristics is especially significant to research this disorder. Therefore, this study was carried out to establish and characterize a new human cell line derived from ovarian clear cell carcinoma.
\end{abstract}

Methods: The cell line $\mathrm{HCH}-3$ was established from a left ovarian tumor of a 41-year-old woman. Characters of the cell line investigated included morphology, chromosome analysis, heterotransplantation, tumor markers, chemosensitivity, and cancer genes.

Results: This cell line has been growing well for 206 months and subcultured more than 50 times. Monolayer cultured cells were multipolar in shape, showing a cobble stone appearance and a tendency of multilayering without contact inhibition. They showed a human karyotype with a modal chromosomal number in the hypotetraploid range. The cells could be transplanted into the subcutis of SCID mice and made tumors looking like the original tumor. $\mathrm{HCH}-3$ cells demonstrated both CA 125 and CA19-9 which were detected immunohistochemically in the original tumor and the heterotransplanted tumor. The cells were not sensitive to agents generally managed in the treatment of gynecological cancers by MTT assay. KRAS and TP53 mutations were discovered in hotspot locations of 50 cancer genes.

Conclusion: $\mathrm{HCH}-3$ is an ovarian clear cell carcinoma cell line in which CA 125 and CA19-9 expression have been clarified. Mutations were discovered in KRAS and TP53 genes. This newly established cell line may be helpful in basic study on ovarian clear cell carcinoma, the etiology of which is not yet entirely recognized.

Keywords: Ovarian clear cell carcinoma; Cell line; MTT assay; CA125; CA19-9; Hot spot; Point mutation

\section{Introduction}

Ovarian clear cell carcinoma is a variant of epithelial ovarian cancer and has a poor outcome for women with advanced stage $[1,2]$. Late reviews recommend that most clear cell carcinomas are related with endometriosis, and endometriosis-associated ovarian cancer tends to occur in younger women, 5-6 years earlier than high-grade serous adenocarcinoma [3,4]. And so, it was thought important to use an ovarian clear cell carcinoma cell line for clinical and basic study of this disease. We report here the establishment and characterization of a new human cell line $(\mathrm{HCH}-3)$ of ovarian clear cell carcinoma that expresses both CA 125 and CA 19-9 and has point mutations in hotspots of KRAS and TP53.

\section{Materials and Methods}

We performed an abdominal simple total hysterectomy, bilateral salpingo-oophorectomy, and omentectomy on a 41-year-old woman with left ovarian cancer International Federation of Gynecology and Obstetrics (FIGO) stage Ic 17 years ago. The patient gave informed consent for act of this research. Intraoperative diagnosis of frozen section was an ovarian adenocarcinoma. Measurement of preoperative serum tumor marker levels showed that CA 125 was $1.417 \mathrm{U} / \mathrm{ml}$ (normal level $<35 \mathrm{U} / \mathrm{ml})$, CA $19-9$ was $181 \mathrm{U} / \mathrm{ml}(<37 \mathrm{U} / \mathrm{ml})$, and carcinoembryonic antigen (CEA) was $0.5 \mathrm{ng} / \mathrm{ml}(<2.5 \mathrm{ng} / \mathrm{ml})$. She was dealt with twice with $100 \mathrm{mg}$ cisplatin (CDDP) and $400 \mathrm{mg}$ etoposide (VP-16) intraperitoneally, and 5 times with $450 \mathrm{mg}$ carboplatin (CBDCA), 60 mg pirarubicin hydrochloride (THP), and $400 \mathrm{mg}$ cyclophosphamide
(CPA) intravenously. Her clinical condition was good after surgery and chemotherapy for at least 5 years.

Culture techniques and media: Tissue section of ovarian tumor was finely minced with a couple of sharp edges in a dish including sans serum Ham's F-12 medium (Flow Laboratories Inc., McLean, VA, USA), mixed gradually with an attractive stirrer in a $0.25 \%$ trypsin arrangement (Flow Laboratories Inc.), centrifuged at $70 \mathrm{~g}$ for $5 \mathrm{~min}$, and put in culture medium at $37^{\circ} \mathrm{C}$ in a humidified chamber with $5 \%$ $\mathrm{CO}_{2}$ and $95 \%$ air. Cells were refined in Ham's F-12 medium in addition to $20 \%$ precolostrum infant calf serum (Mitsubishi Chemical Industries Ltd., Tokyo, Japan) with kanamycin. At that point, subcultures were passaged with $0.1 \%$ trypsin and $0.02 \%$ ethylenediamine-tetraacetic acid (EDTA) arrangement like clockwork. Six months after the essential culture, the centralization of precolostrum infant calf serum in the way of life medium was lessened from $20 \%$ to $10 \%$.

*Corresponding author: Takashi Yamada, Department of Pathology, Osaka Medical College, 2-7 Daigaku-machi, Takatsuki, Osaka 569-8686, Japan, Tel: +81726831221, Fax: +81726846513; E-mail: yamatakashi@mub.biglobe.ne.jp

Received April 21, 2017; Accepted May 10, 2017; Published May 15, 2017

Citation: Yamada T, Hattori K, Satomi H, Okazaki T, Mori H, et al. (2017) Characterization of a Novel Cell Line $(\mathrm{HCH}-3)$ Derived from a Human Ovarian Clear Cell Carcinoma. J Carcinogene Mutagene 8: 292. doi:10.4172/21572518.1000292

Copyright: $\odot 2017$ Yamada T, et al. This is an open-access article distributed under the terms of the Creative Commons Attribution License, which permits unrestricted use, distribution, and reproduction in any medium, provided the original author and source are credited. 
Morphology of the original tumor and cultured cells: Living cells developed in culture flagons were seen with a stage differentiate magnifying instrument. For histological conclusion, the first tumor was fixed in $10 \%$ formalin, implanted in paraffin, and cut into $4 \mu \mathrm{m}$ segments which were recolored with hematoxylin-eosin (HE) and occasional periodic acid Schiff (PAS) stains. Monolayer refined cells on slides were fixed in $90 \%$ ethanol and recolored by Papanicolaou's technique [5].

Growth characteristics: Qualities of cells were inspected in passages $8-10$. Suspensions of $1 \times 10^{5}$ cells were plated in $35 \mathrm{~mm}$ plastic dishes and hatched for 15 days. Next, the quantity of cells from two dishes was measured every other day utilizing a programmed cell counter (Coulter CounterR, Coulter Electronics, Luton, England). The population doubling time and saturation density were resolved from the development bend. For examinations of plating efficiency, $1 \times 10^{2}$ and $2 \times 10^{2}$ single-suspension cells were set into five $60 \mathrm{~mm}$ plastic dishes each and refined for 21 days. Plating efficiency was computed by the proportion of the quantity of colonies (more than 10 cells) to the aggregate number of placed cells. For the mitotic record, monolayer cells were refined for 5 days and responded with $1 \times 10^{-7} \mathrm{M}$ colcemid (Demecolcine Solution, Wako Pure Chemical Industries, Osaka, Japan) for $4 \mathrm{~h}$, put in a $0.2 \% \mathrm{KCl}$ solution for $15 \mathrm{~min}$, and afterward fixed well-ordered in a methanol: acidic corrosive arrangement (3:1). After air-drying, the cells were recolored with Giemsa, and the quantity of mitotic cells in 1,000 cells were measured.

Chromosome analysis: Histograms of chromosome number distribution were decided using 50 metaphase plates. Their karyotypes were analyzed in 10 cells according to the International System for Human Cytogenetic Nomenclature.

Heterotransplantation: Twelve million cells (passage 9) were infused subcutaneously into the dorsal district of 5-week-old SCID mice (SCID/Os, Shionogi, Osaka, Japan). At the point when the tumors had developed to $5-10 \mathrm{~mm}$ in distance across following a month, they were resected and treated for morphological reviews. For histology, the expelled tumors were fixed in $10 \%$ formalin, inserted in paraffin, and recolored with HE and PAS. For electron microscopy, the piece of the first tumor was fixed by plunging in a blend of $1.25 \%$ glutaraldehyde and $1 \%$ paraformaldehyde supported with phosphate buffered saline (PBS), $\mathrm{pH} 7.4$, at $4^{\circ} \mathrm{C}$ for $3 \mathrm{~h}$. In the wake of washing with PBS, the tumor was post fixed with $1 \%$ osmium tetroxide at $4^{\circ} \mathrm{C}$ for $1 \mathrm{~h}$, then washed in PBS, dehydrated in evaluated convergences of ethanol, and installed in Epon 812. Areas $0.5 \mu \mathrm{m}$ thick were cut with a 6000 ultramicrotome (Sorvall, Du Pont, CT, USA) and recolored with toluidine blue. Ultrathin segments showing light gold obstruction shading were cut from the comparing territories in the toluidine blue-recolored areas, twofold recolored with uranyl acetic acid derivation and lead citrate, and saw under a JEM-100SX electron magnifying instrument (JEOL, Tokyo, Japan) at $80 \mathrm{kV}[6]$.

Tumor markers: Medium in which $2 \times 10^{6}$ cells $/ 5 \mathrm{ml}$ were cultured for a week was examined for a fetoprotein (AFP), CA 125, CA 19-9, CA 72-4, CEA, human chorionic gonadotropin (HCG), squamous cell carcinoma (SCC) antigen, and tissue polypeptide antigen (TPA) by radioimmunoassay or chemiluminescent immunoassay.

Immunohistochemical stainings: Deparaffinized 4- $\mu \mathrm{m}$ segments of the first and heterotransplanted tumors on glass slides were recolored immunohistochemically utilizing the universal Immunoenzyme Polymer (UIP) technique (Envision pack; DAKO, Glostrup, Denmark). Slides were plunged in $0.03 \%$ hydrogen peroxidase and absolute methanol to square endogenous peroxidase, washed with PBS, and after that warmed in an autoclave for $20 \mathrm{~min}$. In the wake of cooling, the slides were brooded with essential counter acting agent at room temperature for $40 \mathrm{~min}$ and after that treated with Envision (DAKO) at room temperature for $30 \mathrm{~min}$, trailed by hatching with diaminobenzidine (DAB) for 5-10 min. Antibodies against CA 125 (DAKO) and CA 19-9 (DAKO) were utilized to distinguish tumor markers, and antibodies against human estrogen receptor $\alpha$ (Nichirei Bioscience Inc., Tokyo, Japan) and human progesterone receptor (Nichirei) were utilized to identify hormone receptors. Antibodies against Hepatocyte nuclear factor-1 $\beta$ (HNF-1 $\beta$ ) [7] (Santa Cruz Biotechnology, Inc., Santa Cruz, CA, USA) and Annexin IV [8] (Santa Cruz Biotech), which are occasionally communicated in ovarian clear cell carcinoma, were likewise treated.

Chemosensitivity assays: The impacts of actinomycin D (ACD, MSD KK, Tokyo, Japan), doxorubicin (ADM, Kyowa Hakko Kirin Co., Ltd., Tokyo, Japan), 5-fluorouracil (5-FU, Kyowa Hakko Kirin Co.), mitomycin C (MMC, Kyowa Hakko Kirin Co.), CBDCA (Bristol-Myers K.K., Tokyo, Japan), CDDP (Bristol-Myers), VP-16 (Bristol-Myers), paclitaxel (PTX, Bristol-Myers) [9], and irinotecan SN-38 (CPT-11, Yakult Honsha Co., Ltd., Tokyo, Japan) [10], which are regularly figured out how to treat gynecological malignancies [11], on the refined cells were inspected by 3-(4,5-dimethyl-2-thiazolyl)- 2,5-diphenyl-2H tetrazolium bromide (MTT) assay. The agents were fused in culture medium and utilized immediately. For MTT assay, $5 \times 10^{3}$ cells in $50 \mu \mathrm{l}$ medium were seeded in octaplicate into each well of 96-well microwell plates. For persistent agent exposure studies, different weakened agents in $50 \mu \mathrm{l}$ were put in after $48 \mathrm{~h}$ of brooding. The wells were hatched for $72 \mathrm{~h}$ after the option of agents, after which MTT $(50 \mu \mathrm{l}$ of $2 \mathrm{mg} / \mathrm{ml}$; Wako Pure Chemical Industries, Ltd, Osaka, Japan) was added to each well, and the plates were brooded for $4 \mathrm{~h}$ more. The medium was then disposed of, $150 \mu$ l of dimethyl sulfoxide (DMSO, Sigma, St. Louis, MO, USA) was added to each well, and the plates were shaken for $5 \mathrm{~min}$. The optical density was then measured at $570 \mathrm{~nm}$ on a microplate reader (Bio-Rad Laboratories, Hercules, CA, USA), and the viable grouping of the middle lethal dosage was resolved from the measurements reaction bend (EC50: measurements of agent required to reduction last cell number or optical density in MTT assay to half of control) [12].

\section{Mutational analysis}

DNA was separated from living cells utilizing DNA extraction Kit (PureLinkTM Genomic DNA Mini Kit, Invitrogen, Life Technologies, Carlsbad, CA, USA). Somatic mutations (substitutions, insertions or deletions) were judged utilizing the Ion AmpliSeqTM Cancer Hotspot Panel v2, intended to increase 207 amplicons covering 2800 COSMIC transformations from the 50 most typically educated oncogenes and tumor suppressor genes (Ion Torrent, Life Technologies) (Table 1) $[13,14]$.

\section{Results}

Histopathology of the original tumor: Light microscopy showed the original tumor to be a clear cell carcinoma, cells of which had clear cytoplasm with large nuclei and prominent nucleolei, and a partial hobnail appearance (Figure 1).

Establishment of the cell line: Tissue pieces from the original tumor were cultured and after a 2-month stationary period, certain outgrowths developed. Primarily, mixture of spindle-shaped fibroblasts and epithelial cells was observed, but fibroblasts faded from the cultures upon passaging the cells, which were named $\mathrm{HCH}-3$. The $\mathrm{HCH}-3$ cells 


\begin{tabular}{|c|c|c|}
\hline $\begin{array}{l}\text { UGO Gene } \\
\text { Symbol }\end{array}$ & Description & $\begin{array}{c}\text { Gene } \\
\text { ID }\end{array}$ \\
\hline$A B L 1$ & $\mathrm{ABL}$ proto-oncogene 1 , non-receptor tyrosine kinase & 25 \\
\hline$A K T 1$ & v-akt murine thymoma viral oncogene homolog 1 & 207 \\
\hline$A L K$ & anaplastic lymphoma receptor tyrosine kinase & 238 \\
\hline$A P C$ & adenomatous polyposis coli & 324 \\
\hline ATM & ataxia telangiectasia mutated & 472 \\
\hline$B R A F$ & v-raf murine sarcoma viral oncogene homolog B & 673 \\
\hline $\mathrm{CDH} 1$ & cadherin 1, type 1, E-cadherin (epithelial) & 999 \\
\hline$C D K N 2 A$ & cyclin-dependent kinase inhibitor $2 \mathrm{~A}$ & 1029 \\
\hline CSF1R & colony stimulating factor 1 receptor & 1436 \\
\hline CTNNB1 & catenin (cadherin-associated protein), beta 1 & 1499 \\
\hline EGFR & epidermal growth factor receptor & 1956 \\
\hline$E R B B 2$ & v-erb-b2 avian erythroblastic leukemia viral oncogene homolog 2 & 2064 \\
\hline ERBB4 & v-erb-b2 avian erythroblastic leukemia viral oncogene homolog 4 & 2066 \\
\hline$E Z H 2$ & enhancer of zeste homolog 2 & 2146 \\
\hline FBXW7 & $\begin{array}{l}\text { F-box and WD repeat domain containing } 7, E 3 \text { ubiquitin protein } \\
\text { ligase }\end{array}$ & 55294 \\
\hline FGFR1 & fibroblast growth factor receptor 1 & 2260 \\
\hline FGFR2 & fibroblast growth factor receptor 2 & 2263 \\
\hline FGFR3 & fibroblast growth factor receptor 3 & 2261 \\
\hline FLT3 & fms-related tyrosine kinase 3 & 2322 \\
\hline GNA11 & $\begin{array}{l}\text { guanine nucleotide binding protein (G protein), alpha } 11 \text { (Gq } \\
\text { class) }\end{array}$ & 2767 \\
\hline GNAQ & guanine nucleotide binding protein (G protein), q polypeptide & 2776 \\
\hline GNAS & GNAS complex locus & 2778 \\
\hline HNF1A & HNF1 homeobox A & 6927 \\
\hline HRAS & Harvey rat sarcoma viral oncogene homolog & 3265 \\
\hline IDH1 & isocitrate dehydrogenase 1 (NADP+) & 3417 \\
\hline $\mathrm{IDH} 2$ & isocitrate dehydrogenase $2(\mathrm{NADP}+)$, mitochondrial & 3418 \\
\hline JAK2 & Janus kinase 2 & 3717 \\
\hline JAK3 & Janus kinase 3 & 3718 \\
\hline KDR & kinase insert domain receptor (a type III receptor tyrosine kinase) & 3791 \\
\hline KIT & $\begin{array}{l}\text { v-kit Hardy-Zuckerman } 4 \text { feline sarcoma viral oncogene } \\
\text { homolog }\end{array}$ & 3815 \\
\hline KRAS & Kirsten rat sarcoma viral oncogene homolog & 3845 \\
\hline MET & met proto-oncogene & 4233 \\
\hline MLH1 & mutL homolog 1 & 4292 \\
\hline$M P L$ & myeloproliferative leukemia virus oncogene & 4352 \\
\hline NOTCH1 & Notch 1 & 4851 \\
\hline NPM1 & nucleophosmin (nucleolar phosphoprotein B23, numatrin) & 4869 \\
\hline NRAS & neuroblastoma RAS viral (v-ras) oncogene homolog & 4893 \\
\hline PDGFRA & platelet-derived growth factor receptor, alpha polypeptide & 5156 \\
\hline PIKЗCA & $\begin{array}{l}\text { phosphatidylinositol-4,5-bisphosphate 3-kinase, catalytic subunit } \\
\text { alpha }\end{array}$ & 5290 \\
\hline PTEN & phosphatase and tensin homolog & 5728 \\
\hline PTPN11 & protein tyrosine phosphatase, non-receptor type 11 & 5781 \\
\hline$R B 1$ & retinoblastoma 1 & 5925 \\
\hline$R E T$ & ret proto-oncogene & 5979 \\
\hline SMAD4 & SMAD family member 4 & 4089 \\
\hline SMARCB1 & $\begin{array}{l}\text { SWI/SNF related, matrix associated, actin dependent regulator } \\
\text { of chromatin, subfamily b, member } 1\end{array}$ & 6598 \\
\hline SMO & smoothened, frizzled class receptor & 6608 \\
\hline$S R C$ & $\begin{array}{l}\text { V-src avian sarcoma (Schmidt-Ruppin A-2) viral oncogene } \\
\text { homolog }\end{array}$ & 6714 \\
\hline STK11 & serine/threonine kinase 11 & 6794 \\
\hline TP53 & tumor protein $\mathrm{p} 53$ & 7157 \\
\hline$V H L$ & von Hippel-Lindau tumor suppressor, E3 ubiquitin protein ligase & 7428 \\
\hline
\end{tabular}

Table 1: List of the 50 genes targeted by the Ion AmpliSeqTM Cancer Hotspot Panel v2 (Ion Torrent).

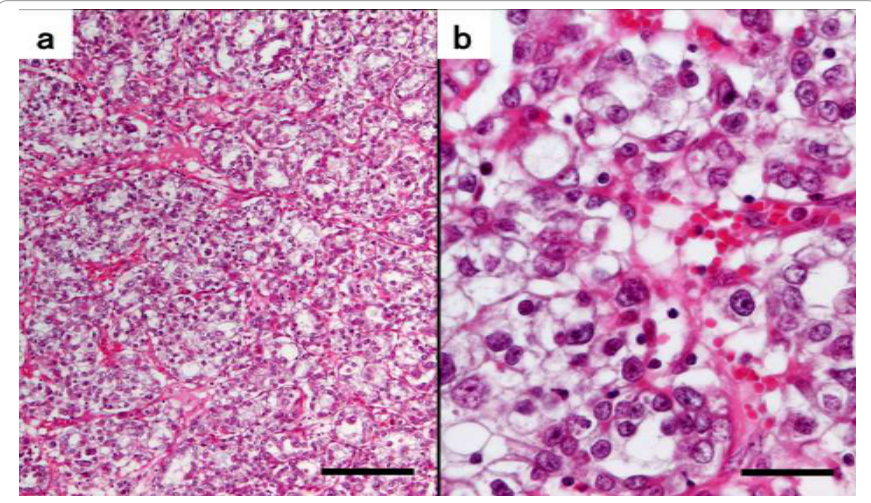

Figure 1: Histology of the original tumor. The left ovarian tumor is a clear cell carcinoma, with cells harboring clear cytoplasm and a partial hobnail appearance, as shown by hematoxylin and eosin (HE) staining. (a, bar=200 $\mu \mathrm{m} ; \mathrm{b}, \mathrm{bar}=50 \mu \mathrm{m}$ )

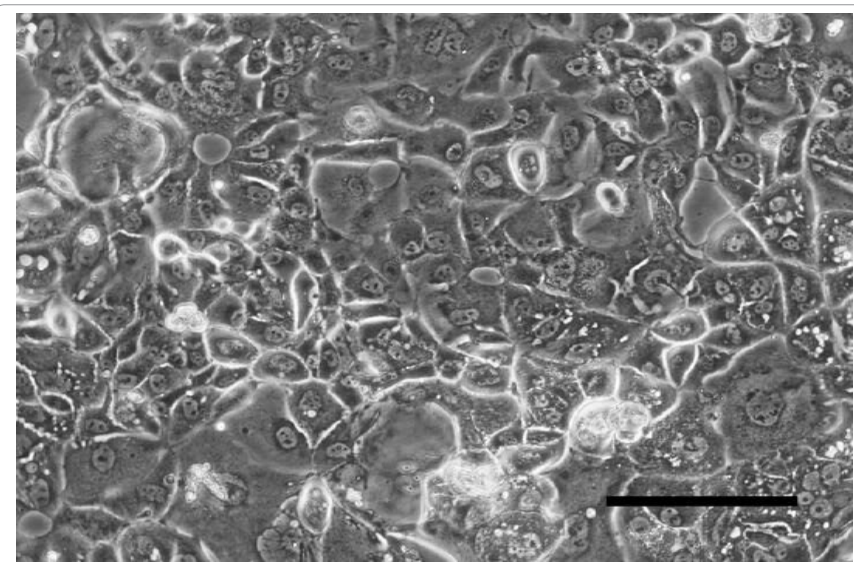

Figure 2: Phase contrast microscopy. The cells show a cobble stone appearance with multilayering. (bar=200 $\mu \mathrm{m}$ ).

grew well, without contact inhibition, for more than 206 months, and more than 50 serial passages were successively performed. They continue to demonstrate constant growth.

Morphology of the cultured cells: The cultured cells grew in monolayer and looked to be epithelial, showing a cobble stone appearance. Multilayering of cells was definitely noted even after they reached confluency (Figure 2). The cells were multilateral and showed neoplastic structures such as unusual aggregation of chromatin granules, thickened nuclear membrane, and multiple prominent nucleoli. Multinucleated giant cells were also observed (Figure 3).

Growth Characteristics: The growth curve was analyzed in passage 8 of the HCH-3 cell line. Three days after culturing, the cells increased logarithmically (Figure 4). The population doubling time, saturation density, plating efficiency, and mitotic index were $82 \mathrm{~h}, 9.7 \times 10^{4}$ cells/ $\mathrm{cm}^{2}, 0.8 \%$, and $10.2 \%$, respectively.

Chromosome Analysis: This cell line showed a modal chromosome number that was in the hypotetraploid range (78-87) (Figure 5). Chromosomal analysis revealed the following abnormalities; $80-86<4 \mathrm{n}>$, XXXX, del (X) (p21) [7], -2 [8], -3 [4], -4[9], add (4) (q31) [5], -5[3], -6[10], -7[4], I (8) (q10) [10], -9[7], add (9) (p11) [3], -10[4], -11[3], -12[8], add (12) (p11) [2], -13[10], -13[8], add (13) (p11) [9], -14[10], -14[4], -15[4], $-16[4],-17[3],-18[9],-19[7],-21[9],-21[3],+4-7 \operatorname{mar}$ (Figure 6). 
Citation: Yamada T, Hattori K, Satomi H, Okazaki T, Mori H, et al. (2017) Characterization of a Novel Cell Line (HCH-3) Derived from a Human Ovarian Clear Cell Carcinoma. J Carcinogene Mutagene 8: 292. doi:10.4172/2157-2518.1000292

Page 4 of 8

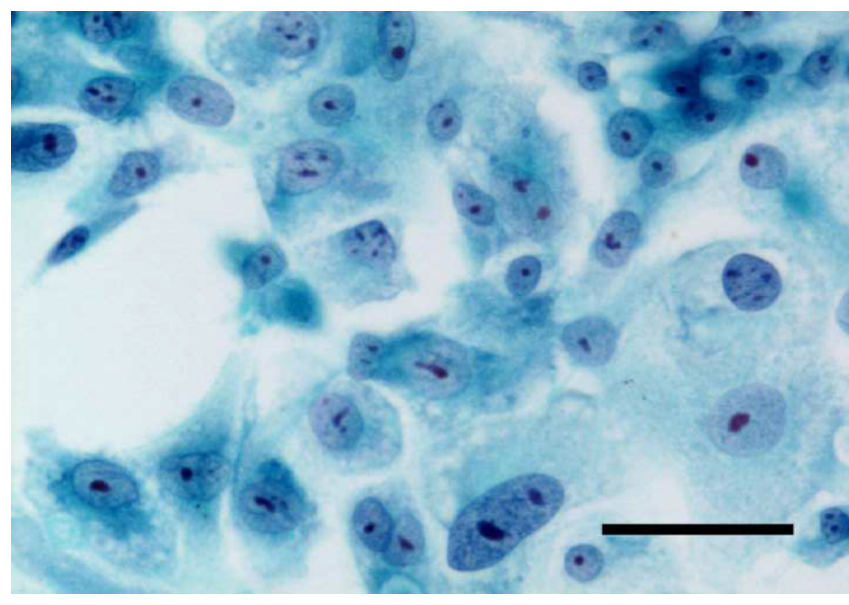

Figure 3: Cytopathology of cultured $\mathrm{HCH}-3$ cells. Multinucleated giant cells with polygonal cytoplasm are seen by Papanicolaou stain. (bar=50 $\mu \mathrm{m}$ ).

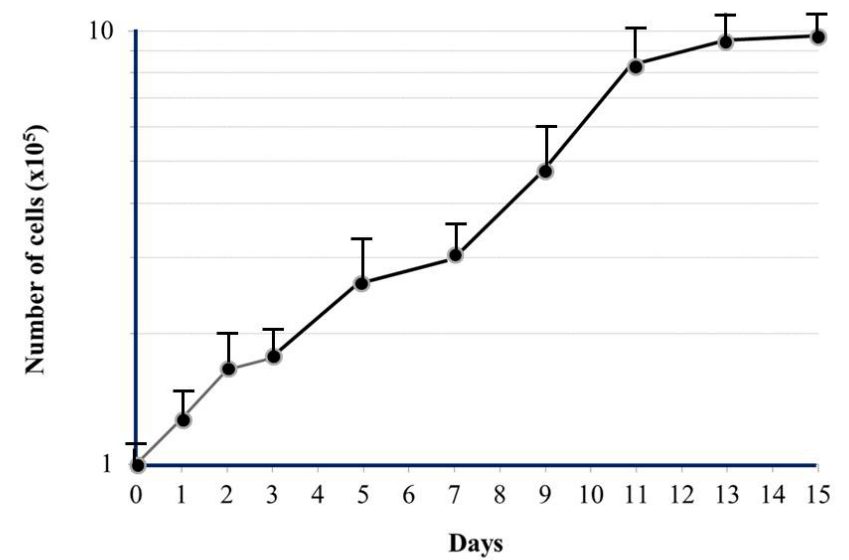

Figure 4: Growth curve of $\mathrm{HCH}-3$. The cells increased logarithmically.

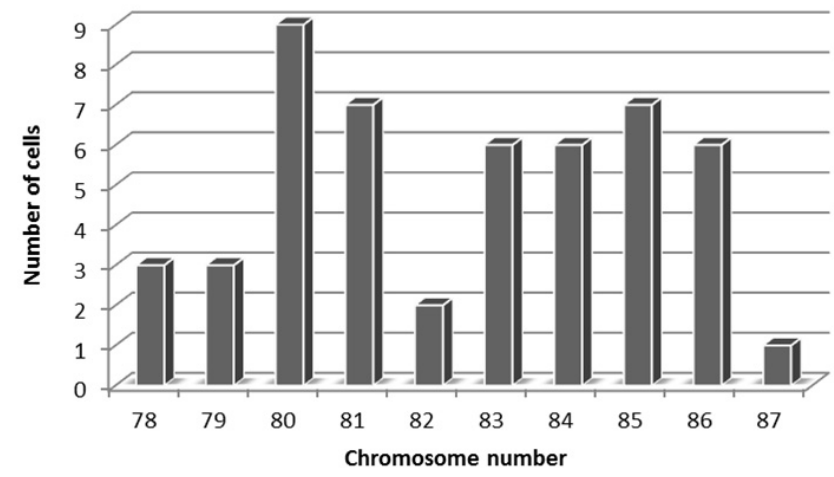

Figure 5: Distribution of chromosomal numbers in $\mathrm{HCH}-3$ (8th generation). The modal number is in the hypotetraploid range.

Heterotransplantation: Histologically, the transplanted tumors were clear cell carcinomas, i.e. with cells showing clear cytoplasm, which strongly looked like the original tumor (Figure 7). They were also positive for PAS stain. Electron microscopy showed that neighboring cells had desmosome-like junctions. The cells had notched nuclei, rich mitochondria in the cytoplasm, and many microvilli on the cell surface (Figure 8). These characters suggested that the cells were epithelial in origin.

\section{Ifll IIR stir in in
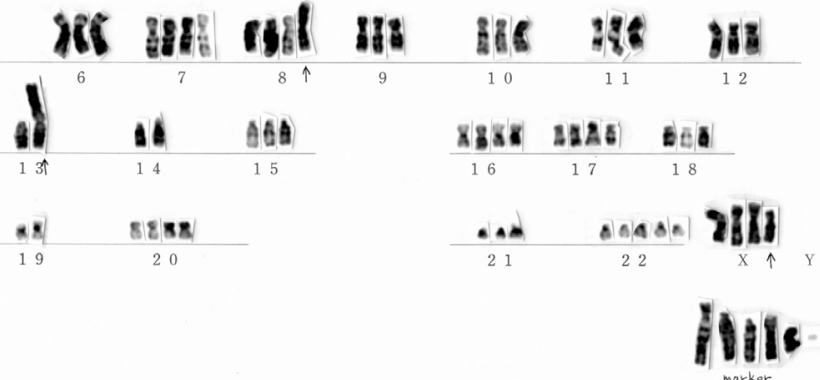

Figure 6: Karyotype of $\mathrm{HCH}-3$ (8th generation). Chromosomal analysis revealed various abnormalities.

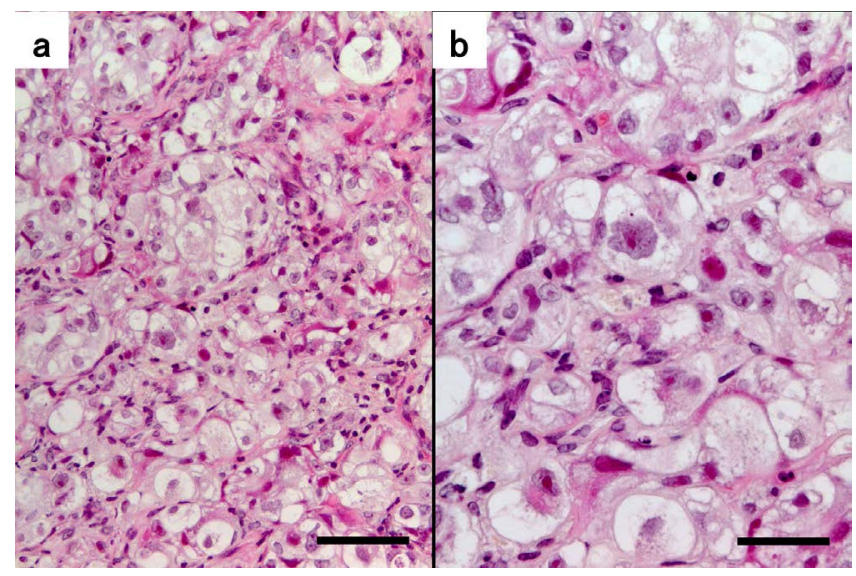

Figure 7: Micrograph of the tumor transplanted into SCID mice. It shows a clear cell carcinoma with large nuclei and prominent nucleolei, strongly looking like the original tumor. (a, bar=100 $\mu \mathrm{m} ; b$, bar $=50 \mu \mathrm{m})$.

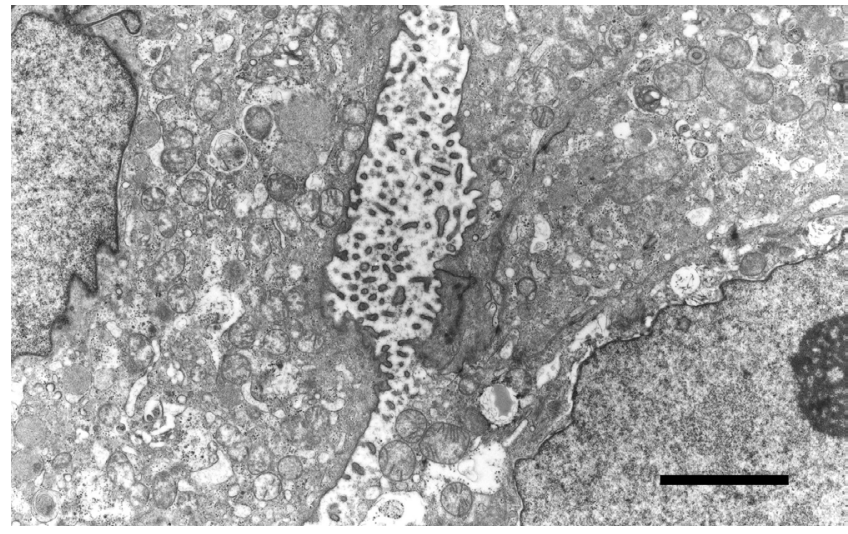

Figure 8: Electron micrograph of the tumor transplanted into SCID mice. The cells have many microvilli on the surface and rich mitochondria in the cytoplasm, and are connected with desmosome-like junctions. (bar=3 $\mu \mathrm{m}$ ). 
Tumor markers: The following tumor markers were positive in the culture medium: CA 19-9, $18 \mathrm{U} / \mathrm{ml}$ and TPA, $>2,000 \mathrm{U} / \mathrm{L}$. In contrast, they were negative for: AFP, $<1 \mathrm{ng} / \mathrm{ml}$; CEA,$<0.5 \mathrm{ng} / \mathrm{ml}$; CA $125,<5$ $\mathrm{U} / \mathrm{ml}$; CA $72-4,4.4 \mathrm{U} / \mathrm{ml}$; HCG- $\beta,<0.1 \mathrm{ng} / \mathrm{ml}$; and SCC antigen, $<0.5$ $\mathrm{ng} / \mathrm{ml}$.

Immunohistochemical stainings: CA 125, CA 19-9, HNF-1a, and Annexin IV were proved immunohistochemically in cancer cells from the original tumor and transplanted tumors (Figures 9 and 10). The expression levels of the cancer antigens (CA125 and CA 19-9) in transplanted tumor were slightly weaker than those in original tumor. Estrogen and progesterone receptors were not detected.

Chemosensitivity: The EC50 values of anti-cancer agents for $\mathrm{HCH}-3$ cells (Figure 11) are listed in Table 2.

Mutational analysis: The amount of $4.3 \mu \mathrm{g}$ DNA was extracted from $2 \times 10^{6}$ living cells. Two variants were discovered in hotspot locations

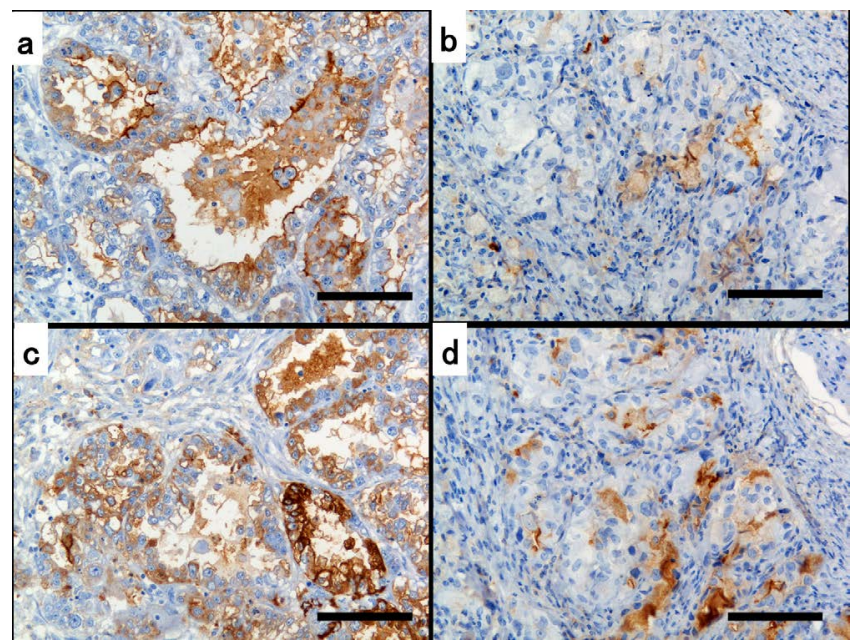

Figure 9: Immunohistochemical stainings of the original tumor $(a, c)$ and heterotransplanted tumor $(b, d)$ for CA $125(a, b)$ and CA 19-9 (c, d). Cancer cells are positive for CA 125 and CA 19-9 (a, b, c, d; bar=100 $\mu \mathrm{m})$.

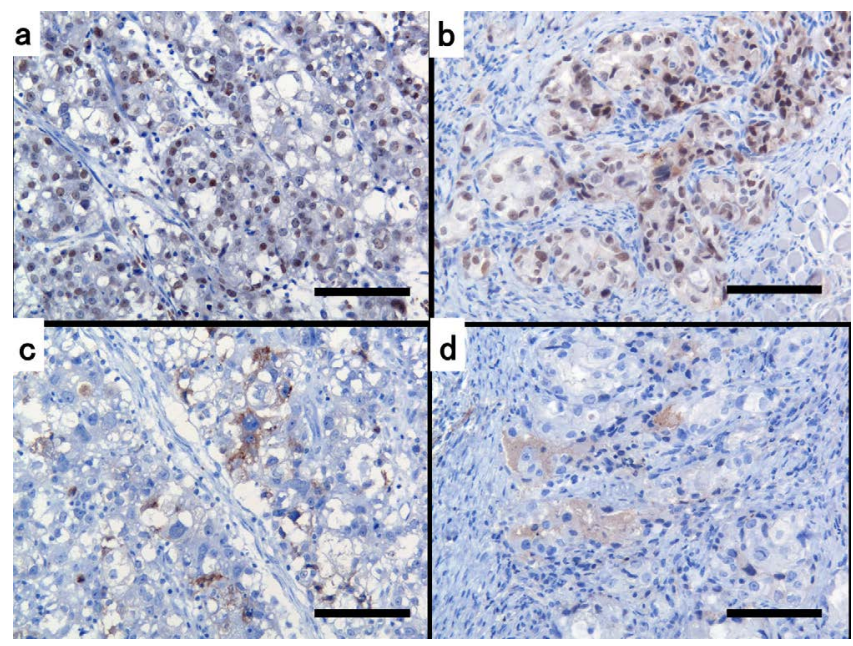

Figure 10: Immunohistochemical stainings of the original tumor $(\mathrm{a}, \mathrm{c})$ and heterotransplanted tumor $(b, d)$ for $\operatorname{HNF}-1 \alpha(a, b)$ and Annexin IV $(c, d)$. Cancer cells are positive for HNF-1 $\alpha$ and Annexin IV (a, b, c, d; bar=100 $\mu \mathrm{m})$.
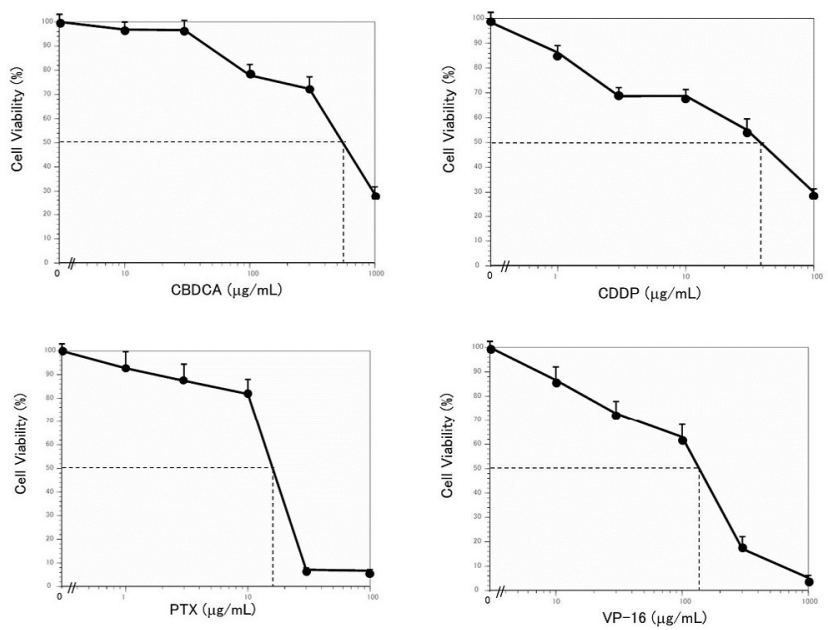

Figure 11: Chemosensitivity of $\mathrm{HCH}-3$ cells. $\mathrm{HCH}-3$ cells are considered nosensitive to CBDCA, CDDP, PTX and VP-16.

\begin{tabular}{|c|c|c|}
\hline Drug & $\mathbf{E C 5 0}(\mathbf{m g} / \mathbf{m L})$ & PPC $(\mathbf{m g} / \mathbf{m L})$ \\
\hline ACD & $>100$ & 0.08 \\
\hline ADM & 0.88 & 0.4 \\
\hline CBDCA & 555.6 & 37.1 \\
\hline CDDP & 38.3 & 8.5 \\
\hline CPT-11 & 2.99 & 0.05 \\
\hline $5-F U$ & 1129 & 15.3 \\
\hline MMC & 22.4 & 2.4 \\
\hline PTX & 16 & 11.8 \\
\hline VP-16 & 136.4 & 13 \\
\hline
\end{tabular}

Table 2: Chemosensitivity using a 3-(4,5-dimethylthiazol-2-yl)-2,5-diphenyl tetrazolium bromide assay. EC50, effective concentration for $50 \%$ kill; PPC, peak plasma concentration taken intravenously; ACD, actinomycin D; ADM, doxorubicin; CBDCA, carboplatin; CDDP, cisplatin; CPT-11, irinotecan hydrochloride; 5-FU, 5-fluorouracil; MMC, mitomycin C; PTX, paclitaxel; VP-16, etoposide.

of 50 cancer genes and 11 of called variants outside of hotspot locations were found (Table 3).

\section{Discussion}

In this report, we established a different cell line, $\mathrm{HCH}-3$, of human clear cell carcinoma of the ovary by culturing tissue parts from a removed tumor, and to get credible proof that this cell line truly exhibits the original tumor and disease, we studied its biological characteristics. We discovered that these cells indicated the following features: 1) histology of the original tumor was clear cell carcinoma and positivity for PAS, HNF-1 $\alpha$, and Annexin IV stainings; 2 ) viable in culture for over 206 months; 3) neoplastic, pleomorphic, and pile up easily without contact inhibition; 4) chromosomes were of a human karyotype with aneuploid distribution; and 5) transplantable into SCID mice and made tumors which histologically similar to the original tumor.

Notwithstanding the advancements in refined expertise, it is as yet difficult to build up a cell line, mainly as a result of blend with fibroblasts, which as a rule grow sooner than epithelial cells and bolster their detachment from the plate. To defeat this, we exploited the way that fibroblasts isolate sooner than epithelial cells by trypsin, and we erased each fibroblast and most epithelial cells, leaving just a couple of colonies of epithelial cells to extend. The cells slowly expanded well 


\begin{tabular}{|c|c|c|c|c|c|c|c|c|c|c|c|c|c|}
\hline S.No & Chromosome & Position & $\begin{array}{c}\text { Ref } \\
\text { Allele }\end{array}$ & Variant & Allele Type & Frequency & $\begin{array}{c}\text { Variant } \\
\text { Type }\end{array}$ & $\begin{array}{c}\text { Allele } \\
\text { Source* }^{*}\end{array}$ & Allele Name & $\begin{array}{c}\text { Gene } \\
\text { Symbol }\end{array}$ & Coverage & AA Ref & $\begin{array}{c}\text { AA } \\
\text { Variant }\end{array}$ \\
\hline 1 & chr2 & 212812097 & $\mathrm{~T}$ & C & Heterozygous & 33 & SNP & Novel & --- & ERBB4 & 1623 & unknown & unknown \\
\hline 2 & chr4 & 1807894 & G & A & Homozygous & 100 & SNP & Novel & --- & FGFR3 & 1912 & $\mathrm{~T}$ & $\mathrm{~T}$ \\
\hline 3 & chr4 & 55141055 & A & G & Homozygous & 100 & SNP & Novel & --- & PDGFRA & 1964 & $\mathrm{P}$ & $P$ \\
\hline 4 & chr4 & 55980239 & C & $T$ & Homozygous & 100 & SNP & Novel & --- & KDR & 1516 & unknown & unknown \\
\hline 5 & chr5 & 112175770 & G & $A$ & Homozygous & 100 & SNP & Novel & --- & APC & 1989 & $\mathrm{~T}$ & $\mathrm{~T}$ \\
\hline 6 & chr5 & 149433596 & TG & GA & Homozygous & 100 & MNP & Novel & --- & CSF1R & 1919 & unknown & unknown \\
\hline 7 & chr9 & 21971106 & G & A & Heterozygous & 33.8 & SNP & Novel & --- & CDKN2A & 1993 & $\mathrm{R}$ & C \\
\hline 8 & chr10 & 43613843 & G & $\mathrm{T}$ & Homozygous & 100 & SNP & Novel & --- & RET & 1996 & L & $L$ \\
\hline 9 & chr11 & 108155167 & $\mathrm{~T}$ & C & Heterozygous & 32.3 & SNP & Novel & --- & ATM & 1999 & $\mathrm{D}$ & $D$ \\
\hline 10 & chr12 & 25398284 & C & $\mathrm{T}$ & Heterozygous & 34.4 & SNP & Hotspot & COSM521 & KRAS & 1981 & G & $\mathrm{D}$ \\
\hline 11 & chr13 & 28610183 & A & G & Heterozygous & 49.9 & SNP & Novel & --- & FLT3 & 1966 & unknown & unknown \\
\hline 12 & chr16 & 68835678 & G & A & Heterozygous & 43.5 & SNP & Novel & --- & $\mathrm{CDH} 1$ & 1999 & $\mathrm{R}$ & $Q$ \\
\hline 13 & chr17 & 7578389 & G & A & Homozygous & 100 & SNP & Hotspot & COSM11090 & TP53 & 1987 & $\mathrm{R}$ & $\mathrm{C}$ \\
\hline
\end{tabular}

Table 3: Variants out side of hotspot locations of 50 cancer genes.

\begin{tabular}{|c|c|c|c|c|c|c|c|}
\hline Cell line & Age & Materials & $\begin{array}{l}\text { Chromosome } \\
\text { Number }\end{array}$ & DT & Transplantability & Immunotaining & Characteristics \\
\hline HUOCA-II (1987) & 51 & ovary & 46 (mode) & 24,28 & Yes & - & tumor angiogenesis factor \\
\hline RMG-I (1988) & 34 & ascites & 47 (mode) & 60 & Yes & BFP, ferritin, PLAP & - \\
\hline OCC1 (1990) & 47 & ascites & $70-77$ & 36,38 & Yes & - & production of CA125 \\
\hline RMG-II (1991) & 53 & ascites & hypertetraploid & 58 & No & $\begin{array}{l}\text { CA125, TPA, MA602-1, } \\
\text { MA602-6 }\end{array}$ & $\begin{array}{l}\text { production of CA125, TPA, MA602-1, } \\
\text { MA602-6 }\end{array}$ \\
\hline OVISE (1995) & 40 & $\begin{array}{l}\text { metastatic } \\
\text { tumor }\end{array}$ & $62(59-65)$ & 60 & Yes & $\begin{array}{c}\text { CA125, CA19-9, EGFR, ER(-), } \\
\text { PgR(-) }\end{array}$ & production of CA19-9, CA125, TPA \\
\hline OVTOKO (1995) & 78 & $\begin{array}{l}\text { metastatic } \\
\text { tumor }\end{array}$ & $78(76-83)$ & 70 & Yes & EGFR, ER(-), PgR(-) & - \\
\hline JHOC-5 (1999) & 47 & ovary & $74-85$ & 52 & No & - & CA125 \\
\hline JHOC-6 (1999) & 43 & recurrent tumor & $46-49$ & 70 & Yes & - & CA125 \\
\hline SMOV-2 (1999) & 46 & tumor & $85-92$ & 48.2 & Yes & - & p53 mutation (-) \\
\hline TAYA (2002) & 43 & ascites & $69-74$ & 50 & No & - & p53 Exon5 point mutation, PTEN mutation (-) \\
\hline RMG-V (2005) & 52 & ascites & $83(77-85)$ & 15.5 & No & - & - \\
\hline TU-OC-1 (2013) & 65 & ovary & 64-69 & 38.4 & Yes & - & PIK3CA mutation $(+)$ \\
\hline TU-OC-2 (2016) & 68 & ovary & $84(41-96)$ & 37.5 & No & ARID1A (-) & PIK3CA mutation (-), p53 mutation (-) \\
\hline $\mathrm{HCH}-1(2016)$ & 67 & ovary & $39-44$ & $\begin{array}{l}48.7 \\
66.4\end{array}$ & Yes & $\begin{array}{l}\text { CA125, CA19-9, HNF-1beta, } \\
\text { Annexin IV, ER(-), PgR(-) }\end{array}$ & production of CA19-9, CA125, TPA \\
\hline $\mathrm{HCH}-3$ & 41 & ovary & $78-87$ & 82 & Yes & $\begin{array}{l}\text { CA125, CA19-9, HNF-1beta, } \\
\text { Annexin IV, ER(-), PgR(-) }\end{array}$ & $\begin{array}{l}\text { production of CA19-9, TPA, KRAS mutation } \\
(+), \text { TP53 mutation }(+)\end{array}$ \\
\hline
\end{tabular}

Table 4: Cell lines from ovarian clear cell carcinoma.

to make evident provinces, and the principal subculture was made 3 months after the primary culture.

Some ovarian clear cell carcinoma cell lines have been applied for basic study, but only 14 of them have had their characteristics explained in detail in the literature (Table 4) [15-26]. HCH-3 cells had the longest doubling time in these cell lines.

Tumor markers are helpful not only in detecting ovarian cancer but also in noticing tumor recurrence or evaluating therapy. In this patient, CA 125 and CA 19-9 were particularly helpful tumor markers because her serum levels were preoperatively high. In the original and transplanted tumors, both were immunohistologically positive for CA 125 and CA 19-9, while this was also demonstrated in two previously reported cell lines (OVISE [19], HCH-1 [26]). However, contradictorily, the HCH-3 cells did not produce much of CA 125 and CA 19-9 in the culture media in vitro. And so, it signifies a good model for the research of ovarian cancers that express tumor markers.
The ovary is believed a target organ of steroid hormones, but OVISE [19], OVTOKO [19], HCH-1 [26] and $\mathrm{HCH}-3$ possess neither estrogen nor progesterone receptors. As the mechanism of action and localization of steroid hormone receptors are still mostly unfamiliar, $\mathrm{HCH}-3$ can be handled as a cell line without hormone receptor for research on receptors.

Not only surgery but also chemotherapy is very important processes for the therapy of ovarian cancer. The CAP (cyclophosphamide, ADM, CDDP) treatment protocol had been generally managed for therapy of ovarian cancer; but, PTX and CBDCA have been lately used although they are not always efficient. Therefore, CPT-11 has been managed for platinum- and taxane-resistant epithelial ovarian cancer [27]. With a specific end goal to assess the impacts of chemotherapeutic meds on $\mathrm{HCH}-3$ cells, chemosensitivity to a board of medicines was resolved utilizing the MTT assay, which is as yet considered a quick and exact strategy for screening for agents responsiveness of refined cells. In vitro affectability was characterized as over half development hindrance at 
pinnacle plasma focuses. Along with this criterion, we verified that $\mathrm{HCH}-3$ cells were not sensitive to agents generally managed in the treatment of gynecological malignant tumors using MTT assay.

Emerging evidence have shown that epigenetic mechanisms including DNA methylation, histone modifications, chromatin remodeling as well as non-coding RNAs, play a critical role in the initiation and development of human carcinomas [28]. Particularly for the ovarian cancer, recent study has shown that histone $\mathrm{H} 3 \mathrm{~K} 9$ methyltransferase G9a serves as a hallmark of its aggression and promotes its peritoneal metastasis [29]. Together with another key histone H3K9 methyltransferase GLP, G9a play an essential role in the establishment and maintenance of $\mathrm{H} 3 \mathrm{~K} 9 \mathrm{me} 1 / 2$ at euchromatin [30]. Mechanistically, G9a suppressed the expression of a set of tumor suppressors, including CDH1, DUSP5, SPRY4, and PPP1R15A in ovarian carcinomas through ectopic establishment of $\mathrm{H} 3 \mathrm{~K} 9 \mathrm{me} 2$ at their promoters [31].

As recent study revealed that G9a also interacts with DNA methyltransferases (DNMTs) and is involved in the maintenance of DNA methylation at particular loci [32], investigation of the patterns of both histone and DNA methylation in normal cells as well as ovarian carcinoma cells might shed light on the obscure mechanisms that required for genesis and progression of this cancer in humans.

On the other hand, various genetic alterations discovered in ovarian cancer. The frequency of driver gene mutations in the altered subtypes (serous, mucinous, endometrioid, clear cell) is controversial. The PIK3CA [33] gene was discovered to be specifically mutated in ovarian clear cell carcinoma. Then ARID1A [34] mutation and the consequent loss of expression are often detected. Rechsteiner et al. [35] reported that TP53 mutations occurred frequently not only in highgrade serous carcinomas $(58.7 \%)$, but also in mucinous carcinoma (57\%) and clear cell carcinoma (52\%). KRAS mutations were chiefly recognized in mucinous carcinoma (57\%) and were concurrently with TP53 mutations (36\%)

As a molecular analysis, somatic mutations were evaluated using Panels of 50 most frequently reported oncogene and tumor suppressor genes. HCH-3 had KRAS and TP53 variants in hotspot locations of 50 genes including PIK3CA, and 11 of called variants outside of hotspot locations. Inappropriately, ARID1A was not contained within this Panel. Thus, a future molecular classification of ovarian cancer should consider the mutational status of all subtypes and may be clarified using new methods for sequencing.

\section{Conclusion}

HCH-3 is an ovarian clear cell carcinoma cell line in which CA 125 and CA19-9 expression have been clarified. Mutations were discovered in KRAS and TP53 genes. As it is difficult to establish a cell line from the malignant tumor individually, the cell line that we established and characterized would be very helpful in basic study on ovarian cancer, specifically clear cell carcinoma, the etiology of which is not yet entirely recognized.

\section{Acknowledgments}

The authors thank Mitsuo Kagawa and Kaname Shimokawa for technical assistance.

\section{References}

1. Goff BA, Sainz de la Cuesta R, Muntz HG, Fleischhacker D, Ek M, et al. (1996) Clear cell carcinoma of the ovary: a distinct histologic type with poor prognosis and resistance to platinum-based chemotherapy in stage III disease. Gynecologic oncology 60: 412-417.
2. Sugiyama T, Kamura T, Kigawa J, Terakawa N, Kikuchi Y, et al. (2000) Clinica characteristics of clear cell carcinoma of the ovary: a distinct histologic type with poor prognosis and resistance to platinum-based chemotherapy. Cancer 88: 2584-2589.

3. del Carmen MG, Birrer M, Schorge JO (2012) Clear cell carcinoma of the ovary: a review of the literature. Gynecologic oncology 126: 481-490.

4. Rauh-Hain JA, Winograd D, Growdon WB, Schorge JO, Goodman AK, et al. (2012) Prognostic determinants in patients with uterine and ovarian clear carcinoma. Gynecologic oncology 125: 376-380.

5. Papanicolaou GN (1942) A new procedure for staining vaginal smears. Science 95: 438-439.

6. Masuda H, Fujihira S, Ueno H, Kagawa M, Katsuoka Y, et al. (2003) Ultrastructural study on cytotoxic effects of cyclosporine $A$ in spermiogenesis in rats. Med Electron Microsc 36: 183-191.

7. Kato N, Sasou S, Motoyama T (2006) Expression of hepatocyte nuclear factor1 beta (HNF-1beta) in clear cell tumors and endometriosis of the ovary. Modern pathology : an official journal of the United States and Canadian Academy of Pathology, Inc 19: 83-89.

8. Miao Y, Cai B, Liu L, Yang Y, Wan X (2009) Annexin IV is differentially expressed in clear cell carcinoma of the ovary. International journal of gynecological cancer : official journal of the International Gynecological Cancer Society 19: 1545-1549.

9. Tamura T, Sasaki Y, Nishiwaki Y, Saijo N (1995) Phase I study of paclitaxel by three-hour infusion: hypotension just after infusion is one of the major doselimiting toxicities. Japanese journal of cancer research: Gann 86: 1203-1209.

10. Taguchi T, Wakui A, Hasegawa K, Niitani H, Furue H, et al. (1990) [Phase clinical study of CPT-11. Research group of CPT-11]. Gan to kagaku ryoho Cancer \& chemotherapy 17: 115-120.

11. Yamada T, Ueda M, Otsuki Y, Ueki M, Sugimoto O (1991) Establishment and characterization of a cell line (OMC-3) originating from a human mucinous cystadenocarcinoma of the ovary. Gynecol Oncol 40: 118-128.

12. Twentyman PR, Luscombe $M$ (1987) A study of some variables in a tetrazolium dye (MTT) based assay for cell growth and chemosensitivity. $\mathrm{Br} \mathrm{J}$ Cancer 56: 279-285.

13. Rothe F, Laes JF, Lambrechts D, Smeets D, Vincent D, et al. (2014) Plasma circulating tumor DNA as an alternative to metastatic biopsies for mutational analysis in breast cancer. Annals of oncology : official journal of the European Society for Medical Oncology / ESMO 25: 1959-1965.

14. Ji JH, Oh YL, Hong M, Yun JW, Lee HW, et al. (2015) Identification of Driving ALK Fusion Genes and Genomic Landscape of Medullary Thyroid Cancer. PLoS genetics 11: e1005467.

15. Ishiwata I, Ishiwata C, Soma M, Ishikawa H (1987) Establishment of HUOCA-II, a human ovarian clear cell adenocarcinoma cell line, and its angiogenic activity. J Natl Cancer Inst 78: 667-673.

16. Nozawa S, Tsukazaki K, Sakayori M, Jeng CH, lizuka R (1988) Establishment of a human ovarian clear cell carcinoma cell line (RMG-I) and its single cell cloning--with special reference to the stem cell of the tumor. Hum Cell 1: 426435 .

17. Wong WS, Wong YF, Ng YT, Huang PD, Chew EC, et al. (1990) Establishment and characterization of a new human cell line derived from ovarian clear cell carcinoma. Gynecol Oncol 38: 37-45.

18. Nozawa S, Yajima M, Sasaki H, Tsukazaki K, Aoki D, et al. (1991)A new CA125 like antigen (CA602) recognized by two monoclonal antibodies against a newly established ovarian clear cell carcinoma cell line (RMG-II). Jpn J Cancer Res 82: 854-861.

19. Gorai I, Nakazawa T, Miyagi E, Hirahara F, Nagashima Y, et al. (1995) Establishment and characterization of two human ovarian clear cell adenocarcinoma lines from metastatic lesions with different properties. Gynecol Oncol 57: 33-46.

20. Yamada K, Tachibana T, Hashimoto H, Suzuki K, Yanagida S, et al. (1999) Establishment and characterization of cell lines derived from serous adenocarcinoma (JHOS-2) and clear cell adenocarcinoma (JHOC-5, JHOC-6) of human ovary. Human cell: official journal of Human Cell Research Society 12: 131-138.

21. Yonamine K, Hayashi K, lida T (1999) Establishment and characterization of 
Citation: Yamada T, Hattori K, Satomi H, Okazaki T, Mori H, et al. (2017) Characterization of a Novel Cell Line (HCH-3) Derived from a Human Ovarian Clear Cell Carcinoma. J Carcinogene Mutagene 8: 292. doi:10.4172/2157-2518.1000292

Page 8 of 8

human ovarian clear cell adenocarcinoma cell line (SMOV-2), and its cytotoxity by anticancer agents. Human cell : official journal of Human Cell Research Society 12: 139-148

22. Saga Y, Suzuki M, Machida S, Ohwada M, Sato I (2002) Establishment of a new cell line (TAYA) of clear cell adenocarcinoma of the ovary and its radiosensitivity. Oncology 62: 180-184.

23. Aoki D, Suzuki N, Susumu N, Noda T, Suzuki A, et al. (2005) Establishment and characterization of the RMG-V cell line from human ovarian clear cell adenocarcinoma. Hum Cell 18: 143-146.

24. Itamochi H, Kato M, Nishimura M, Oumi N, Oishi T, et al. (2013) Establishment and characterization of a novel ovarian clear cell adenocarcinoma cell line, TUOC-1, with a mutation in the PIK3CA gene. Human cell 26: 121-127.

25. Sato S, Itamochi H, Oumi N, Chiba Y, Oishi T, et al. (2016) Establishment and characterization of a novel ovarian clear cell carcinoma cell line, TU-OC-2, with loss of ARID1A expression. Human cell 26: 131-145.

26. Yamada T, Hattori K, Satomi H, Okazaki T, Mori H, et al. (2016) Establishment and characterization of a cell line $(\mathrm{HCH}-1)$ originating from a human clear cell carcinoma of the ovary. Journal of ovarian research 9: 32.

27. Matsumoto K, Katsumata N, Yamanaka Y, Yonemori K, Kohno T, et al. (2006) The safety and efficacy of the weekly dosing of irinotecan for platinum- and taxanesresistant epithelial ovarian cancer. Gynecologic oncology 100: 412-416.

28. Sharma S, Kelly TK, Jones PA (2010) Epigenetics in cancer. Carcinogenesis 31: $27-36$.
29. Hua KT, Wang MY, Chen MW, Wei LH, Chen CK, et al. (2014) The H3K9 methyltransferase $\mathrm{G} 9 \mathrm{a}$ is a marker of aggressive ovarian cancer that promotes peritoneal metastasis. Molecular cancer 13: 189

30. Tachibana M, Matsumura $Y$, Fukuda M, Kimura H, Shinkai $Y$ (2008) G9a/ GLP complexes independently mediate $\mathrm{H} 3 \mathrm{~K} 9$ and DNA methylation to silence transcription. The EMBO journal 27: 2681-2690.

31. Wozniak RJ, Klimecki WT, Lau SS, Feinstein Y, Futscher BW (2007) 5-Aza2'-deoxycytidine-mediated reductions in G9A histone methyltransferase and histone $\mathrm{H} 3 \mathrm{~K} 9$ di-methylation levels are linked to tumor suppressor gene reactivation. Oncogene 26: 77-90.

32. Zhang T, Termanis A, Ozkan B, Bao XX, Culley J, et al. (2016) G9a/GLP Complex Maintains Imprinted DNA Methylation in Embryonic Stem Cells. Cell reports 15: 77-85.

33. Kuo KT, Mao TL, Jones S, Veras E, Ayhan A, et al. (2009) Frequent activating mutations of PIK3CA in ovarian clear cell carcinoma. The American journal of pathology 174: 1597-1601.

34. Jones S, Wang TL, Shih le M, Mao TL, Nakayama K, et al. (2010) Frequent mutations of chromatin remodeling gene ARID1A in ovarian clear cell carcinoma. Science 330: 228-231.

35. Rechsteiner M, Zimmermann AK, Wild PJ, Caduff R, von Teichman A, et al. (2013) TP53 mutations are common in all subtypes of epithelial ovarian cancer and occur concomitantly with KRAS mutations in the mucinous type. Experimental and molecular pathology 95: 235-241. 